\section{Recycled Newspaper Reduces Nutrient Leaching from Container-grown Poinsettia}

\author{
J.S. Glenn ${ }^{1}$ and C.H. Gilliam ${ }^{2}$ \\ Department of Horticulture, Auburn University, Auburn, AL 36849
}

J.H. Edwards
USDA-ARS, National Soil Dynamics Laboratory, Auburn, AL 36831

G.J. Keever ${ }^{2}$

Department of Horticulture, Auburn University, Auburn, AL 36849

P.R. Knight ${ }^{4}$

Mississippi State University, 711 West North Street, Poplarville, MS 39470

J.W. Olive ${ }^{5}$

Ornamental Horticulture Substation, P.O. Box 8276, Mobile, AL 36689-0276

Additional index words. Euphorbia pulcherrima, nitrogen, phosphorus, recycled paper, remediation, runoff

\begin{abstract}
Two experiments were conducted to evaluate recycled newspaper products as nutrient filters in the bottom of containers. In Expt. 1 with poinsettia, Euphorbia pulcherrima Willd. ex Klotzsch 'Glory', three paper products were evaluated: ground paper, paper crumble, and paper pellets; each placed 2 or $3 \mathrm{~cm}$ deep in the bottom of containers, so that drainage holes were covered. Leachate samples were collected at the first irrigation after each liquid fertilization. Nitrate $\left(\mathrm{NO}_{3}^{-}-\mathrm{N}\right)$ and ammonium $\left(\mathrm{NH}_{4}{ }^{+}-\mathrm{N}\right)$ leachate concentrations were reduced up to $84 \%$ with recycled paper pellets, compared to the control (no paper). Recycled paper retained up to $732 \mathrm{mg}$ of nitrogen $(\mathrm{N})$ per container (paper pellets $3 \mathrm{~cm}$ deep). Shoot dry weight was reduced with paper pellets but was not affected by ground paper or paper crumble. In Expt. 2, 'Freedom Red' poinsettias were grown with either single weekly applications of $500 \mathrm{mg} \cdot \mathrm{L}^{-1} \mathrm{~N}$ from Peter's $20 \mathrm{~N}-4.3 \mathrm{P}-16.6 \mathrm{~K}$, or 200 $\mathrm{mg} \cdot \mathrm{L}^{-1} \mathrm{~N}$ at each irrigation ( 2 or 3 times a week, as needed). Recycled paper treatments included paper crumble or paper pellets placed $2.5 \mathrm{~cm}$ deep in the bottom of containers, and a control without paper. Leachate $\mathrm{NO}_{3}{ }^{-}-\mathrm{N}$ and $\mathrm{NH}_{4}{ }^{+}-\mathrm{N}$ concentrations were reduced up to $100 \%$ and $94 \%$, respectively, 6 days after planting (DAP), and up to $57 \%$ and $50 \%$, respectively, 25 DAP with paper crumble compared to nonpaper control. Paper pellets in the bottom of containers retained up to $776 \mathrm{mg} \mathrm{N}$ per container. Poinsettia shoot dry weight was lowest with paper pellets in the bottom of containers and continuous fertilization.
\end{abstract}

Greenhouse and nursery facilities in the southeastern United States use large volumes of ground and surface water to satisfy irrigation demands of container-grown plants in pine bark-based substrate. As a result of high water inputs, high porosity, low substrate cation exchange capacity, and limited container volume, current production of container-grown plants requires high intensity fertilization. These practices may lead to high concentrations of nutrients, especially nitrate, in runoff water. In order to improve water quality from container production facilities, a best management practices (BMPs) manual for water man-

Received for publication 27 Dec. 2000. Accepted for publication 24 Sept. 2001. Use of trade names does not imply endorsement of the products named nor criticism of similar ones not named.

${ }^{1}$ Graduate Research Assistant.

${ }^{2}$ Professor.

${ }^{3}$ Soil Scientist, deceased.

${ }^{4}$ Associate Horticulturist.

${ }^{5}$ Superintendent. agement was developed for the southern region of the United States (Yeager et al., 1997). Best management practices designed to reduce container nursery runoff and improve water quality include cyclic irrigation and terrain modification (wetlands, grassed waterways, filter strips, mulching, and collection basins). However, many nursery sites are not suitable for implementation of needed BMPs, or the BMPs available at a particular site do not adequately control nutrient contamination of runoff leaving the property. In the past, concern about high nutrient concentrations in container effluent motivated many nursery growers to use controlled release fertilizers instead of liquid fertilizers; however, nutrient losses can still be high (Yeager and Cashion, 1993). Thus, for many container nursery facilities, the only alternative for remediation of effluent water may be in the container itself.

One product with potential for remediation of nursery effluent water is recycled paper. In the past few years, recycled paper products have been evaluated for several potential uses in horticultural production. Craig and Cole (1997) evaluated a recycled paper product as a potential plant growth substrate, and found that as the percentage of recycled paper in the substrate mix increased from $0 \%$ to $100 \%$, spirea size and foliar $\mathrm{N}$ decreased, suggesting that recycled paper may have immobilized $\mathrm{N}$.

In laboratory tests, columns of soil amended with recycled newspaper products adsorbed $\mathrm{N}$ from water (Busscher et al., 1999). Treatments were waste paper mixed into the substrate, waste paper not mixed, and control. Less $\mathrm{N}$ leached from columns with paper, especially when waste paper was mixed into the substrate (69\% less than columns without paper). For columns with paper, less leaching of N $(51 \%$ to $69 \%$ ) and higher soil $\mathrm{N}$ content (11\% to $19 \%$ ) at the end of the experiment suggest that paper held some N, preventing it from leaching.

Glenn et al. (2000) examined the effect of recycled paper mulch on fertilization practices of petunia (Petunia $\times$ hybrida Hort. Vilm.Andr.). Fertilizer application methods included incorporation, topdressing over or topdressing under $2.5 \mathrm{~cm}$ of recycled paper pellets (Enviroguard; Tascon, Inc., Houston, Texas). Paper mulch reduced $\mathrm{N}$ in leachate and petunia growth, regardless of fertilizer application method. Recycled paper pellets retained up to $40 \%$ of the total $\mathrm{N}$ applied over the paper mulch. When fertilizer was incorporated into the substrate, paper pellet mulch retained $8 \%$ of the total $\mathrm{N}$ applied as a result of capillary movement of substrate solution. These data demonstrated the ability of recycled paper pellets to rapidly adsorb $\mathrm{N}$ from solution. The objective of the current investigation was to evaluate nutrient filtration potential of several recycled paper products with different fertilization programs.

\section{Materials and Methods}

Expt. 1. Three paper products were evaluated: ground paper, paper pellets, and paper crumble. To obtain the ground paper, newsprint was ground using a hammer mill equipped with a series of three screens, the smallest $\approx 0.76 \mathrm{~mm}$. Ground paper was compressed using pelletizing equipment to form extruded paper pellets $\approx 6.4 \mathrm{~mm}$ in diameter and $38 \mathrm{~mm}$ long. Pellets were passed through a granulator with variable pressure plates to obtain the recycled paper crumble. Paper products were manufactured by Tascon, Inc., Houston, Texas. Each paper product was placed 2 or $3 \mathrm{~cm}$ deep in the bottom of 16.5 -cm top diameter containers $(10.0-\mathrm{cm}$ bottom diameter, $1800 \mathrm{~mL}$ total available volume), so that all drainage holes were covered. Actual paper weights (8\% moisture content) for 2- and 3-cm depths, respectively, were: ground paper 25 and $50 \mathrm{~g}$, crumble paper 70 and $140 \mathrm{~g}$, and paper pellets 130 and $260 \mathrm{~g}$. Weight of paper products doubled with $50 \%$ depth increase because of cone-like container shape. The control treatment did not have paper in the bottom of the containers. Each container was filled with the same volume $(1300 \mathrm{~mL})$ of 3 pine bark : 1 peatmoss [PB/P (by volume)] substrate amended with 
$3.6 \mathrm{~kg} \cdot \mathrm{m}^{-3}$ dolomitic limestone, $1.2 \mathrm{~kg} \cdot \mathrm{m}^{-3}$ gypsum, and $0.9 \mathrm{~kg} \cdot \mathrm{m}^{-3}$ Micromax (Scotts Co., Marysville, Ohio). A 7 pine bark : 1 sand [PB/S (by volume)] substrate amended similarly to the PB/P substrate was also included as a second control to compare nutrient leaching from two commonly used substrates in the southeastern United States.

V-14 red poinsettia 'Glory' plants were transplanted on 12 Sept. 1997 and placed in a polyethylene-covered greenhouse under $40 \%$ shade. Temperatures in the greenhouse ranged from 16 to $31^{\circ} \mathrm{C}$. Plants were fertilized at potting with $250 \mathrm{~mL}$ of $200 \mathrm{mg} \cdot \mathrm{L}^{-1} \mathrm{~N}$ solution of $20 \mathrm{~N}-8.8 \mathrm{P}-16.6 \mathrm{~K}$ fertilizer (Peter's 20-20-20; Scotts Co.), then weekly with $250 \mathrm{~mL}$ of $250 \mathrm{mg} \cdot \mathrm{L}^{-1} \mathrm{~N}$ for 2 weeks, and $250 \mathrm{~mL}$ of $500 \mathrm{mg} \cdot \mathrm{L}^{-1} \mathrm{~N}$ weekly until 6 Nov. 1997. Ten days after planting (DAP), $14 \mathrm{~N}-6.2 \mathrm{P}-11.6 \mathrm{~K}$ controlled release fertilizer (Osmocote 14-14-14; Scotts Co.) was topdressed at $1 \mathrm{~g} /$ container $\mathrm{N}$.

Leachate samples from individual containers were collected using the Virginia Tech Extraction Method (VTEM) (Yeager et al., $1983)$ at the first irrigation after liquid fertilization and at 3, 25, 50, and 83 DAP. Leachate from five replications per treatment was collected and samples were frozen in plastic vials for subsequent analysis of $\mathrm{NO}_{3}{ }^{-} \mathrm{N}$ and $\mathrm{NH}_{4}{ }^{+}$ $\mathrm{N}$ (Sims et al., 1995), and P concentrations (Watanabe and Olsen, 1965). Twelve weeks after transplanting, foliage and bract colors were recorded and plants were harvested for shoot dry weight and paper $\mathrm{N}$ determination. Foliar color was determined on a 1 to 5 scale, where $1=$ white, 2 = yellow, $3=$ light green, 4 $=$ medium green, and $5=$ dark green. Bract color was determined on a 1 to 3 scale, where 1 = light red, $2=$ medium red, and $3=$ dark red. Paper samples from the bottom of the containers were analyzed for $\mathrm{N}$ content using a Kjeldahl method (Bremner, 1996). Total $\mathrm{N}$ was determined by multiplying initial dry weight of paper by $\mathrm{N}$ concentration and subtracting the initial paper $\mathrm{N}$ content per container.

The experiment was conducted in a completely randomized design with eight treatments and eight single container replications. Data were analyzed using the GLM procedure of the Statistical Analysis System (SAS Institute, Cary, N.C.). Multiple contrasts were used to calculate the significance of main effects of paper product depth and type. Means separation was performed using Fisher's protected least significant difference (LSD), where appropriate.

Expt. 2. In 1998, the study was repeated with the following changes: three paper types (paper crumble, paper pellet, and no paper) and two fertilization programs (weekly feed or continuous feed) were used in a $3 \times 2$ factorial arrangement. Each paper product was placed 2-cm deep in the bottom of 16.5-cm diameter containers. Paper crumble weight was $60 \mathrm{~g}$ and paper pellets $150 \mathrm{~g}$. Paper crumble and pellets contained 37 and $93 \mathrm{mg} \mathrm{N}$ per container, respectively. Each container was filled with $1300 \mathrm{~mL}$ of 3 pine bark : 1 peatmoss substrate amended similarly to the first experiment, except $\mathrm{MgSO}_{4}$ was added at $0.2 \mathrm{~kg} \cdot \mathrm{m}^{-3}$.
Fertilization treatments included either 250 $\mathrm{mL}$ of $500 \mathrm{mg} \cdot \mathrm{L}^{-1} \mathrm{~N}$ weekly from a $20 \mathrm{~N}-4.3 \mathrm{P}-$ 16.6K fertilizer (Peter's 20-10-20; Scotts Co.), or $250 \mathrm{~mL}$ of $200 \mathrm{mg} \cdot \mathrm{L}^{-1} \mathrm{~N}$ at each irrigation (two or three times a week, as needed). Rooted cuttings of poinsettia 'Freedom' were transplanted on 10 Sept. 1998. All plants were fertilized with $250 \mathrm{~mL}$ of $200 \mathrm{mg} \cdot \mathrm{L}^{-1} \mathrm{~N}$ from 20N-8.8P-16.6K (Peter's 20-10-20), at potting. Eight days after transplanting, $14 \mathrm{~N}-6.2 \mathrm{P}-$ 11.6K controlled release fertilizer (Osmocote 14-14-14) was topdressed at $1 \mathrm{~g} /$ container $\mathrm{N}$. Liquid fertilizer treatments began $15 \mathrm{DAP}$ and were discontinued on 6 Nov. 1998 (57 DAP).

Leachate samples were collected on all replications $6,25,50$, and 83 DAP. Growth indices [(height + width $1+$ width 2)/3] were determined 83 DAP. Plants were harvested 12 weeks after transplanting and shoot dry weight, foliar $\mathrm{N}$ and paper $\mathrm{N}$ were determined.

\section{Results and Discussion}

Expt. 1. Leachate nutrient concentrations. Paper pellets and paper crumble reduced
$\mathrm{NO}_{3}^{-}-\mathrm{N}$ and $\mathrm{NH}_{4}{ }^{+}-\mathrm{N}$ leachate concentrations similarly throughout the study. Leachate $\mathrm{NO}_{3}{ }^{-}-\mathrm{N}$ concentrations were reduced $79 \%$, $84 \%$ and $76 \%$ with $3 \mathrm{~cm}$ of paper pellets compared to the PB/P control 3, 25, and 50 DAP, respectively (Table 1). A paper crumble layer 3-cm deep reduced leachate $\mathrm{NO}_{3}{ }^{-}-\mathrm{N}$ concentrations $64 \%$ and $49 \%$ compared to the PB/ $\mathrm{P}$ control 25 and 50 DAP, respectively. Leachate $\mathrm{NH}_{4}{ }^{+}-\mathrm{N}$ concentrations were reduced up to $84 \%$ with $3 \mathrm{~cm}$ of paper pellets compared to $\mathrm{PB} / \mathrm{P}$ control (50 DAP), and up to $71 \%$ with $3 \mathrm{~cm}$ of paper crumble (25 and 50 DAP) (Table $1)$. Ground paper did not provide adequate control of $\mathrm{N}$ leaching. Throughout the experiment $\mathrm{NO}_{3}^{-}-\mathrm{N}$ and $\mathrm{NH}_{4}^{+}-\mathrm{N}$ leachate concentrations with $2 \mathrm{~cm}$ of ground paper were greater than or equal to those of $\mathrm{PB} / \mathrm{P}$ control. A ground paper layer 3-cm deep reduced $\mathrm{NO}_{3}{ }^{-}$$\mathrm{N}$ and $\mathrm{NH}_{4}{ }^{+}-\mathrm{N}$ leachate concentrations 25 and 50 DAP compared to PB/P control; however, on other dates $\mathrm{N}$ leaching was greater than or equal to $\mathrm{PB} / \mathrm{P}$ control.

Leachate $\mathrm{NO}_{3}{ }^{-} \mathrm{N}$ concentration did not differ between the $\mathrm{PB} / \mathrm{P}$ control and the $\mathrm{PB} / \mathrm{S}$ control (Table 1); however, the PB/P control

Table 1. Nitrate $\left(\mathrm{NO}_{3}{ }^{-} \mathrm{N}\right)$, ammonium $\left(\mathrm{NH}_{4}{ }^{+}-\mathrm{N}\right)$, and phosphorus $(\mathrm{P})$ concentrations in container leachate, as affected by paper in the bottom of containers. Expt. 1.

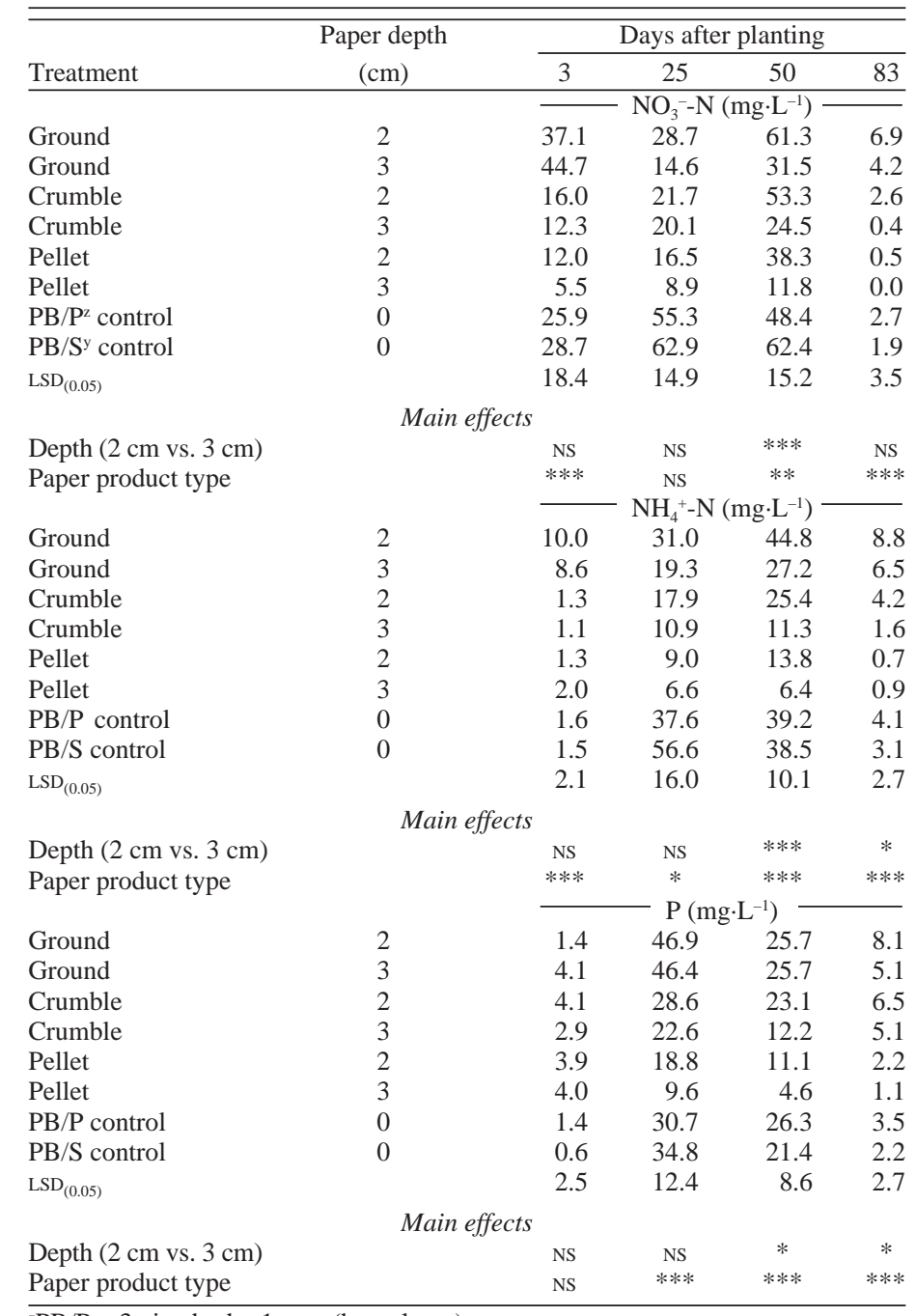

${ }^{2} \mathrm{~PB} / \mathrm{P}=3$ pine bark : 1 peat (by volume).

${ }^{\mathrm{y}} \mathrm{PB} / \mathrm{S}=7$ pine bark $: 1$ sand (by volume).

Ns, ${ }^{* * *, * * *}$ Nonsignificant or significant at $P=0.05,0.01$, or 0.001 , respectively. 
leached $34 \%$ less $\mathrm{NH}_{4}{ }^{+}$-N than $\mathrm{PB} / \mathrm{S}$ control 25 DAP. Paper product depth did not affect $\mathrm{NO}_{3}{ }^{-}-\mathrm{N}$ leaching initially, however, 50 DAP $\mathrm{NO}_{3}^{-}$-N leachate concentration was lower with $3 \mathrm{~cm}$ of paper than with $2 \mathrm{~cm}$ (Table 1). Leachate $\mathrm{NH}_{4}{ }^{+} \mathrm{N}$ concentration was lower with $3 \mathrm{~cm}$ than with $2 \mathrm{~cm}$ of paper product 50 and 83 DAP.

At 3 DAP all paper products leached as much or more $\mathrm{P}$ than the $\mathrm{PB} / \mathrm{P}$ control; with ground paper this trend continued throughout the experiment. These elevated initial concentrations are not surprising since paper products contain significant amounts of $\mathrm{P}$ (48-80 $\mathrm{mg} \cdot \mathrm{kg}^{-1}$ ) (Smith et al., 1997). After 3 DAP, paper pellets reduced P leachate concentration more consistently than ground paper or paper crumble. Three $\mathrm{cm}$ of paper pellets decreased leachate $\mathrm{P}$ concentrations by $69 \%$ and $83 \%$ compared to the PB/P control 25 and 50 DAP, respectively, while crumble paper reduced $\mathrm{P}$ leachate concentration compared to PB/P only 50 DAP.

Plant response. Bract color did not differ among depth or product treatments (data not shown). Paper product depth did not affect shoot dry weight (Table 2). Shoot dry weight was reduced with paper pellets $2-$ and $3-\mathrm{cm}$ deep ( $45 \%$ and $57 \%$ lower compared to $\mathrm{PB} / \mathrm{P}$ control). With $3 \mathrm{~cm}$ of paper pellets, foliage was lighter in color and growth index was $17 \%$ lower than in the PB/P control plants (Table 2). These results are similar to those of Glenn et al. (2000) who demonstrated that plant size and quality were reduced when recycled paper pellets were used as mulch and fertilizer was applied on top of the mulch. Crumble paper produced poinsettia plants similar in size and quality to those of the nonpaper control, while decreasing $\mathrm{NO}_{3}^{-}-\mathrm{N}$ and $\mathrm{NH}_{4}{ }^{+}-\mathrm{N}$ leachate concentrations similarly to paper pellets.

Paper $N$. Total $\mathrm{N}$ retained by paper was greater with crumble paper and paper pellets than with ground paper (Table 2). The $3-\mathrm{cm}$ deep paper pellets retained more than twice the $\mathrm{N}$ of paper pellets $2-\mathrm{cm}$ deep, and almost seven times more than $2 \mathrm{~cm}$ of ground paper. These differences may be explained by the actual weight of paper products in the respective treatments. The respective paper weights (g) for 2-and 3-cm deep were: ground paper 25 and 50, crumble paper 70 and 140, and paper pellets 130 and 260 . Total $\mathrm{N}$ retained in paper ranged from 4.0 to $4.3 \mathrm{mg} \cdot \mathrm{g}^{-1} \mathrm{~N}$ for ground paper, $3.9 \mathrm{mg} \cdot \mathrm{g}^{-1} \mathrm{~N}$ for crumble paper, and 2.6 to $2.8 \mathrm{mg} \cdot \mathrm{g}^{-1} \mathrm{~N}$ for paper pellets. Thus, the difference in adsorbed $\mathrm{N}$ was probably due to increased density, rather than volume. We speculate that the high density of paper pellets reduced shoot dry weight. When actively growing root tips reached the pellet layer, paper pellets competed with plants for $\mathrm{N}$. About $1.9 \mathrm{~g}$ of $\mathrm{N}$ was applied to each container, thus $3 \mathrm{~cm}$ of paper pellets retained $39 \%$ of the $\mathrm{N}$ applied. These data concur with results obtained by Busscher et al. (1999), where substrates containing paper retained $11 \%$ to $19 \%$ more $\mathrm{N}$ than the control with no paper, and Glenn et al. (2000), who showed that pellets retained up to $40 \%$ of the total $\mathrm{N}$ applied over a paper pellet mulch.

Table 2. Shoot dry weight, growth index, and foliar color rating of 'Glory' poinsettia, and total N absorbed by paper, as affected by paper in the bottom of containers. Expt. 1.

\begin{tabular}{|c|c|c|c|c|c|}
\hline Paper type & Depth & $\begin{array}{c}\text { Shoot } \\
\text { dry wt (g) }\end{array}$ & $\begin{array}{l}\text { Growth } \\
\text { index }^{z}\end{array}$ & $\begin{array}{l}\text { Foliar } \\
\text { color }^{y}\end{array}$ & $\begin{array}{c}\text { Paper N } \\
\text { (mg/container) }\end{array}$ \\
\hline Ground & 2 & 31.6 & 45.8 & 4.1 & 108 \\
\hline Ground & 3 & 24.2 & 49.6 & 4.0 & 199 \\
\hline Crumble & 2 & 29.0 & 46.1 & 4.0 & 273 \\
\hline Crumble & 3 & 22.9 & 43.7 & 3.8 & 542 \\
\hline Pellet & 2 & 16.3 & 44.3 & 3.8 & 339 \\
\hline Pellet & 3 & 12.8 & 39.6 & 3.5 & 732 \\
\hline $\mathrm{PB} / \mathrm{P}^{\mathrm{w}}$ control & 0 & 29.8 & 47.6 & 3.9 & --- \\
\hline $\mathrm{PB} / \mathrm{S}^{\mathrm{v}}$ control & 0 & 24.0 & 47.4 & 4.0 & --- \\
\hline $\mathrm{LSD}_{0.05}$ & 11.8 & 4.8 & 0.2 & 98 & \\
\hline \multicolumn{6}{|c|}{ Main effects } \\
\hline Depth $(2 \mathrm{~cm}$ vs. $3 \mathrm{~cm})$ & & NS & NS & $* * *$ & * \\
\hline Paper product type & & $* *$ & $* *$ & $* * *$ & $* * *$ \\
\hline
\end{tabular}

${ }^{2}$ Growth index = (width $1+$ width $2+$ height $) / 3$.

${ }^{y}$ Foliar color scale: 1 = white, 2 = yellow, $3=$ light green, $4=$ medium green, $5=$ dark green.

${ }^{\mathrm{x}}$ Total $\mathrm{N}$ in paper was determined by multiplying dry weight of paper by $\% \mathrm{~N}$.

${ }^{\mathrm{w}} \mathrm{PB} / \mathrm{P}=3$ pine bark : 1 peat (by volume).

${ }^{\mathrm{P}} \mathrm{PB} / \mathrm{S}=7$ pine bark : 1 sand (by volume).

ns, *,******Nonsignificant or significant at $P=0.05,0.01,0.001$, respectively.

Table 3. Effects of fertilization program and recycled paper on $\mathrm{NO}_{3}{ }^{-}-\mathrm{N}$ and $\mathrm{NH}_{4}{ }^{-}-\mathrm{N}$ concentrations in container leachate. Expt. 2.

\begin{tabular}{lcrrrr}
\hline & & \multicolumn{4}{c}{ Days after planting } \\
\cline { 3 - 6 } Main effects & & 6 & 25 & 50 & 83 \\
\cline { 3 - 6 } Fertilization & Weekly & $1.7 \mathrm{a}^{\mathrm{y}}$ & $132.1 \mathrm{a}$ & $64.2 \mathrm{a}$ & $41.7 \mathrm{a}$ \\
\multirow{3}{*}{ Paper } & Continuous & $2.1 \mathrm{a}$ & $123.3 \mathrm{a}$ & $55.3 \mathrm{a}$ & $26.9 \mathrm{a}$ \\
& Crumble & $0.0 \mathrm{~b}$ & $85.6 \mathrm{~b}$ & $41.5 \mathrm{~b}$ & $30.0 \mathrm{~b}$ \\
& Pellet & $1.0 \mathrm{~b}$ & $98.3 \mathrm{~b}$ & $43.7 \mathrm{~b}$ & $12.7 \mathrm{~b}$ \\
& No paper & $4.8 \mathrm{a}$ & $199.1 \mathrm{a}$ & $94.0 \mathrm{a}$ & $60.2 \mathrm{a}$ \\
\cline { 3 - 6 } Fertilization & & $\mathrm{NH}_{4}{ }^{-}-\mathrm{N}$ & $\left(\mathrm{mg} \cdot \mathrm{L}^{-1}\right)$ & \\
\cline { 3 - 5 } Paper & Weekly & $15.6 \mathrm{a}$ & $99.8 \mathrm{a}$ & $38.6 \mathrm{a}$ & $22.1 \mathrm{a}$ \\
& Continuous & $14.6 \mathrm{a}$ & $95.3 \mathrm{a}$ & $34.6 \mathrm{a}$ & $17.6 \mathrm{a}$ \\
& Crumble & $2.5 \mathrm{~b}$ & $77.4 \mathrm{~b}$ & $30.5 \mathrm{~b}$ & $15.5 \mathrm{~b}$ \\
& Pellet & $3.5 \mathrm{~b}$ & $60.1 \mathrm{~b}$ & $31.0 \mathrm{~b}$ & $9.0 \mathrm{~b}$ \\
& No paper & $39.2 \mathrm{a}$ & $155.1 \mathrm{a}$ & $48.3 \mathrm{a}$ & $35.1 \mathrm{a}$ \\
\hline
\end{tabular}

${ }^{\mathrm{z}}$ Fertilization $\times$ paper interaction was nonsignificant at $P=0.05$.

${ }^{y}$ Mean separation within main effects by Fisher's protected LSD at $P=0.05$.

Expt. 2. Leachate nutrient concentrations. Fertilization program did not affect leachate $\mathrm{NO}_{3}{ }^{-}-\mathrm{N}$ or $\mathrm{NH}_{4}{ }^{-}-\mathrm{N}$ concentration (Table 3). Paper crumble and paper pellets reduced leachate $\mathrm{NO}_{3}{ }^{-}-\mathrm{N}$ and $\mathrm{NH}_{4}{ }^{+}-\mathrm{N}$ concentrations similarly compared to controls without paper on all sampling dates. Leachate $\mathrm{NO}_{3}{ }^{-}-\mathrm{N}$ concentrations were reduced $100 \%$ or $79 \%$ with paper crumble or paper pellets, respectively, compared to the control 6 DAP. Leachate $\mathrm{NH}_{4}^{+}-\mathrm{N}$ concentrations were reduced $94 \%$ or 91\% with paper crumble or paper pellets, respectively, compared to the control 6 DAP. Compared to the control, paper crumble and paper pellets reduced leachate $\mathrm{NO}_{3}{ }^{-} \mathrm{N}$ concentrations $57 \%$ and $51 \%$, respectively, and leachate $\mathrm{NH}_{4}{ }^{+}-\mathrm{N}$ concentrations were reduced $50 \%$ and $61 \%$ with paper crumble and paper pellets, respectively, 25 DAP. Leachate $\mathrm{N}$ concentration was lower with pellets and crumble compared to control for the rest of the experiment. These results are similar to those of Expt. 1, in which $\mathrm{N}$ leaching from containers amended with paper crumble and paper pellets was similar and less than that of the control without paper.

Phosphorus leachate concentration was not affected by fertilization program or paper type (data not shown). Control leachate P concen- trations were 67\% lower than in Expt. 1, due to a lower $\mathrm{P}$ content of the fertilizer $(20 \mathrm{~N}-8.8 \mathrm{P}$ $16.6 \mathrm{~K}$ vs. $20 \mathrm{~N}-4.3 \mathrm{P}-16.6 \mathrm{~K})$.

Plant response. Foliar N levels were not affected by fertilization program (Table 4). Foliar N levels were reduced $12 \%$ in plants grown with paper crumble compared to the control. Fertilization program interacted with paper treatment for shoot dry weight. Shoot dry weights were similar regardless of paper treatment with weekly fertilization, but dry weights of plants with paper pellets were lower than those of plants with paper crumble or no paper under continuous fertilization (data not shown). Less $\mathrm{N}$ was applied to each container on the continuous fertilization program $(1.6 \mathrm{~g})$ than in the weekly program $(1.9 \mathrm{~g})$. The difference in applied $\mathrm{N}$ combined with the high density of paper pellets may have resulted in greater reduction of available $\mathrm{N}$ by pellets in the continuous fertilization program.

Paper N. Paper in the bottom of containers retained $30 \%$ or $33 \%$ of the total $\mathrm{N}$ applied with weekly or continuous fertilization programs, respectively. Paper pellets retained twice as much $\mathrm{N}$ per container as paper crumble, probably because weight of the same volume of paper pellets was $\approx 2.5$ times greater than that of paper crumble. Similar results occurred 
Table 4. Effects of fertilization program and recycled paper on foliar N content of 'Freedom Red' poinsettia and total $\mathrm{N}$ retained by paper. Expt. 2 .

\begin{tabular}{lccc}
\hline \hline Main effects & & Foliar N $\left(\mathrm{g}^{\circ} \mathrm{kg}^{-1}\right)$ & Paper N (mg/container) \\
\hline Fertilization (F) & Weekly & $49 \mathrm{a}^{\mathrm{z}}$ & $569 \mathrm{a}$ \\
& Continuous & $48 \mathrm{a}$ & $523 \mathrm{a}$ \\
Paper (P) & Crumble & $46 \mathrm{~b}$ & $316 \mathrm{~b}$ \\
& Pellet & $48 \mathrm{ab}$ & $776 \mathrm{a}$ \\
& No paper & $52 \mathrm{a}$ & --- \\
\hline
\end{tabular}

${ }^{2}$ Mean separation within main effects by Fisher's protected LSD at $P=0.05$.

in Expt. 1, where paper pellets retained up to $35 \%$ more $\mathrm{N}$ than paper crumble at the same depth. In summary, these tests show that paper products in the bottom of containers reduce nutrient concentrations in container leachate. Recycled paper pellets and paper crumble resulted in less nutrient leaching and greater $\mathrm{N}$ retention than with ground paper. This was apparently due to the greater density and thus higher exchange capacity of paper pellets and paper crumble compared to the ground paper. In addition to possessing excellent remediation capabilities, paper crumble did not affect poinsettia growth or quality. Because recycled paper is inexpensive and readily available, this technique may provide a cost effective alter- native to other BMPs when a greenhouse or nursery site is not suitable for a particular $\mathrm{BMP}$, or the BMPs available do not adequately control nutrients in runoff leaving the property.

\section{Literature Cited}

Bremner, J.M. 1996. Nitrogen-Total. In: D.L. Sparks (ed.). Methods in soil analysis. Part 3Chemical methods. Amer. Soc. Agron. and Soil Sci. Soc. Amer. J., Madison, Wis.

Busscher, W., P. Bauer, J. Edwards, and J. Sadler. 1999. Nitrogen leaching in paper-amended soil columns. Commun. Soil Sci. Plant Anal. 30:293306.

Craig, P. and J. Cole. 1997. Recycled paper as a growth substrate in container production of Spiraea. HortScience 32:455 (Abstr.).

Glenn, J.S., C.H. Gilliam, J.H. Edwards, G.J. Keever, and P.R. Knight. 2000. Recycled waste paper mulch reduces available container $\mathrm{N}$. J. Environ. Hort. 18:188-191.

Sims, G.K., T.R. Ellsworth, and R.L. Mulvaney. 1995. Microscale determination of inorganic nitrogen in water and soil extracts. Commun. Soil Sci. Plant Anal. 26:303-316.

Smith, D.R., C.H. Gilliam, J.H. Edwards, D.J. Eakes, and J.D. Williams. 1997. Recycled waste paper as a landscape mulch. J. Environ. Hort. 15:191-196.

Watanabe, F.S., and S.R. Olsen. 1965. Test of an ascorbic acid method for determining phosphorus in water and $\mathrm{NaHCO}_{3}$ extracts from soil. Soil Sci. Soc. Amer. Proc. 29:677-678.

Yeager, T. and G. Cashion. 1993. Controlled-release fertilizers affect nitrate nitrogen runoff from container plants. HortTechnology 3:174-177.

Yeager, T., C. Gilliam, T. Bilderback, D. Fare, A. Niemiera, and K. Tilt. 1997. Best management practices guide for producing container-grown plants. Southern Nursery Assn., Marietta, Ga.

Yeager, T.H., R.D. Wright, and S.J. Donahue. 1983. Comparison of pour-through and saturated pine bark extract N, P, K, and pH levels. J. Amer. Soc. Hort. Sci. 108:112-114. 